\title{
INSTARS OF THREE ANT SPECIES
}

\author{
By George. C. Wheeler and Jeanette Wheeler ${ }^{*}$ \\ Research Associates, Florida Collection of Arthropods \\ Gainesville, Florida
}

All instars of Pseudomyrmex seminole, Trichoscapa membranifera and Colobopsis abdita are described and figured. The larva of the genus Trichoscapa has not been previously described.

\section{SUBFAMILY PSEUDOMYRMECINAE}

Revised characterization. Body profile crematogastroid. Trophothylax well developed. Body hairs numerous; of 3 types: (1) minute to short, unbranched, smooth, generally distributed; (2) moderately long, unbranched, smooth, one to a few of each ventrolateral surface of most somites; (3) long, with tortuous shaft and uncinate tip; 2-6 in a row on each thoracic somite and several anterior abdominal somites. Antennae minute. Head hairs moderately numerous, minute to short, smooth and unbranched. Mouth parts small. Mandibles mostly tetraponeroid, but may be dinoponeroid, platythyreoid or pristomyrmecoid.

\section{Genus PSEUdOMYRMEX Lund}

Revised characterization. Body profile crematogastroid. Trophothylax well developed. Body hairs numerous, of 3 types: (1) minute to short, smooth, unbranched, on all somites; (2) sparse, unbranched, smooth, short to moderately long, one or a few of the longest on each ventrolateral surface of a few abdominal somites; (3) long, with tortuous shaft and uncinate tip; 2-6 in a row across dorsum of each thoracic and a few abdominal somites. Antennae

\footnotetext{
${ }^{*}$ Mailing address: 3358 NE 58th Avenue, Silver Springs, Florida 32688. Manuscript received by the editor February 20, 1991.

The Editorial Board of Psyche notes with deep regret the death of George C. Wheeler on 19 February 1991, the day before we received this article written jointly with Jeanette Wheeler. The collaborative research of the Wheelers on larval anatomy and evolution extended over forty years and greatly enriched our knowledge of ant biology. George Wheeler had been a member of the Cambridge Entomological Club since 1922.
} 
minute. Head hairs moderately numerous, minute to short, unbranched, smooth. Mouth parts small. Mandible tetraponeroid or dinoponeroid or platythyreoid or pristomyrmecoid. Maxilla large, swollen ventrolaterally. Labium small.

\section{Pseudomyrmex seminole Ward}

Figures 1-5.

Fifth instar (=mature larva). Length (through spiracles) about 4 mm. Similar to Ps. aliodore (1956:379). Profile crematogastroid. Thirteen differentiated somites. Anus posteroventral. Trophothylax well developed. Integument feebly spinulose on abdomen. Body hairs moderately numerous and uniformly distributed (except none in or near trophothylax). Of 3 types: (1) $0.008-0.025 \mathrm{~mm}$ long, unbranched, without alveolus and articular membrane; (2) $0.075-0.26 \mathrm{~mm}$ long, longest near each spiracle on AIII and AVII, unbranched, with alveolus and articular membrane, few on each somite; (3) $0.2-0.25 \mathrm{~mm}$ long, uncinate with flexuous shaft, 4 in a row across dorsum of each T1-AIV, reduced to 0.075 on AV. Cranium subquadrangular, slightly wider than long. Antenna small, with 3 sensilla; above midlength of cranium. Head hairs short (0.006-0.025 mm long) moderately numerous, unbranched with stout base. Labrum paraboloidal, wide, 3-lobed; anterior surface with 3-4 sensilla midventrally and with transverse ridges dorsally; ventral surface with about 8 sensilla; posterior surface with numerous transverse ridges bearing spinules. Mandible dinoponeroid, small, with 5 small subequal teeth apically, apical and subapical teeth blunt, apex heavily sclerotized. Maxilla bulging laterally; palp a low rounded knob with 5 sensilla; galea represented by 2 sensilla on a slight elevation; ca. 3 unbranched hairs (ca. $0.006 \mathrm{~mm}$ long) between palp and galea; apex narrowly round-pointed and with a few small isolated spinules. Labium small, subrectangular; palp represented by 5 sensilla on a slight elevation; an isolated sensillum between each palp and opening of sericteries, the latter a short transverse slit. Hypopharynx with numerous transverse ridges bearing numerous spinules.

Fourth instar. Length (through spiracles) about $2.2 \mathrm{~mm}$. Similar to mature larva except as follows. Spiracles on T2 $0.01 \mathrm{~mm}$ in diameter, on AVIII $0.009 \mathrm{~mm}$. Body hairs: (1) short spikes (0.006-0.019 mm long); (2) 0.013-0.25 mm long, one on each 


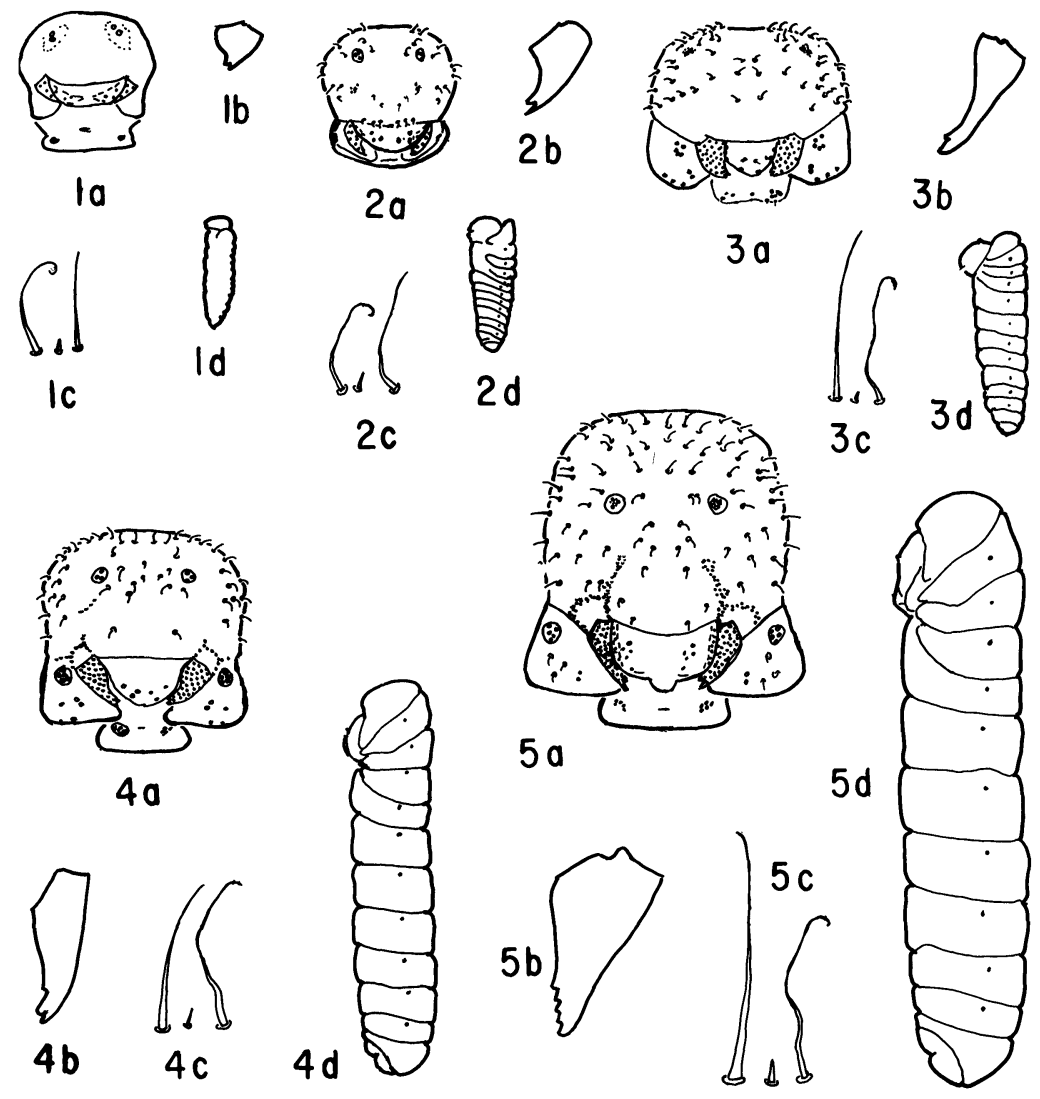

Figures 1-5. Pseudomyrmex seminole. 1, First instar; 2, second instar; 3, third instar; 4, fourth instar; 5, fifth instar (=mature larva). a, Head in anterior view, $\times 60$; $b$, left mandible in anterior view, $\times 130$; c, body hairs, $\times 100$; , larva in side view (hairs omitted), $\times 20$. 
lateral surface of AIII-AVI. Cranium wider than long. Pleurostoma feebly developed. Head hairs fewer (about 48), longer (0.013-0.038 $\mathrm{mm}$ long). Labrum without median projection. Mandible narrower, with only 3 teeth; subapical tooth large and nearly overlapping apical tooth anteriorly, basal tooth smaller. Maxilla with hairs ventral to palp and galea, the latter represented by two adjacent sensilla.

Third instar. Length (through spiracles) about $1.6 \mathrm{~mm}$. Similar to fourth instar except as follows. Body widest at AI and AII and tapering to posterior end which is formed by $\mathrm{AX}$; no praesaepium evident. Spiracles on T2 and T3 $0.008 \mathrm{~mm}$ in diameter, on AI 0.01 and on AII-AVIII $0.006 \mathrm{~mm}$ in diameter. Body hairs: (1) $0.006-0.013 \mathrm{~mm}$ long; (2) $0.006-0.18 \mathrm{~mm}$ long, with alveolus and articular membrane; (3) $0.063-0.18 \mathrm{~mm}$, uncinate on T1-AIV. Cranium transversely subelliptical. Antenna a distinct knob. Head hairs about $0.013 \mathrm{~mm}$ long. Mandible slender; with apical and subapical teeth only. Maxilla with subconical apex.

Second instar. Length (through spiracles) $1.4 \mathrm{~mm}$. Similar to third instar except as follows. All 13 somites distinct. Spiracles about $0.003 \mathrm{~mm}$ in diameter. Body hairs on T1-AVII only; (3) $0.08-0.13 \mathrm{~mm}$ long, uncinate, 4 on dorsum of each T1-AIV. Cranium about as broad as long. Head hairs 0.003-0.008 mm long, about 40. Labrum broadly paraboloidal; with 9 sensilla; ventral surface with a medial patch of rows of spinules.

First instar. Length (through spiracles) ca. $1.1 \mathrm{~mm}$. Similar to second instar except as follows. Body straight; head on anterior end; anus on posterior end. Spiracles on T2 and T3 $0.003 \mathrm{~mm}$, AI $0.009 \mathrm{~mm}$, AII $0.006 \mathrm{~mm}$ and AVIII $0.004 \mathrm{~mm}$ in diameter. Body hairs sparse. Of 3 types: (1) $0.001-0.006 \mathrm{~mm}$, without alveolus and articular membrane; (2) $0.044-0.05 \mathrm{~mm}$ long, slightly curved, one on each lateral surface of AIII-AIV; (3) $0.05-0.1 \mathrm{~mm}$ long, uncinate. Cranium transversely subelliptical. No head hairs visible. Mandible feebly sclerotized short and wide; abruptly narrowed apically to 2 small teeth.

Material studied: Numerous larvae from Homestead Air Force Base, Florida, G. C. and J. Wheeler, FL \#56. 


\section{Tribe Dacetini \\ Genus TRICHOSCAPA Emery}

Body profile pheidoloid but shorter and stouter. Body hairs sparse. Of 2 types: (1) short with bifid tip to long with flexuous denticulate branches; (2) uncinate. Mandible ectatommoid. Labium with lateral sclerotized bands. Head hairs few, straight, some bent to $90^{\circ}$.

Brown (1948:113) stated that Trichoscapa adults are " ... quite distinct from the great majority of the short-mandibulate forms ... It is certainly distinct from all other dacetine genera I have seen." The same may be said for the larva of Trichoscapa, because the larvae of the Dacetini are also a heterogeneous group. Its body profile is not typically pheidoloid; it approaches paedalgoid, but there is no neck and the anus is not far enough forward.

\section{Trichoscapa membranfera Emery}

Figures 6-11.

Fifth instar (=mature larva). Length (through spiracles) about $1.6 \mathrm{~mm}$. Profile pheidoloid but shorter and stouter. Anus with small posterior lip. Spiracles on T2 $0.005 \mathrm{~mm}$, on AVIII $0.004 \mathrm{~mm}$ in diameter. No spinules found on integument. Body hairs sparse; none on venter of T1-T3. Of 2 types: (1) $0.03-0.063 \mathrm{~mm}$ long, the shorter with short bifid tip, the longer with branches long and flexuous and with a few fine denticles; (2) about $0.1 \mathrm{~mm}$ long, uncinate, 4 in a row across dorsum of AI-AV. Cranium suboctagonal (0.18 mm wide and $0.138 \mathrm{~mm}$ long). Pleurostoma well developed. Each antenna with 3 sensilla on a small sclerotized area, surrounded by a larger feebly sclerotized area. Head hairs few (about $33)$, moderately long $(0.016-0.075 \mathrm{~mm}$ long), straight to bent about $90^{\circ}$. Labrum bilobed; twice as wide as long; each half of anterior surface with 4 sensilla; each half of ventral surface with 2 contiguous and 2 isolated sensilla; each half of posterior surface with 3 sensilla and minute spinules in short arcuate rows. Mandible ectatommoid; apical tooth long, 2 large medial teeth. Maxilla small, apex short, rounded; palp a short irregular peg with 5 sensilla apically; galea digitiform with 2 apical sensilla, each with a long spinule. Labium wide and short, with lateral sclerotized bands; palp represented by 5 sensilla on a short peg; an 

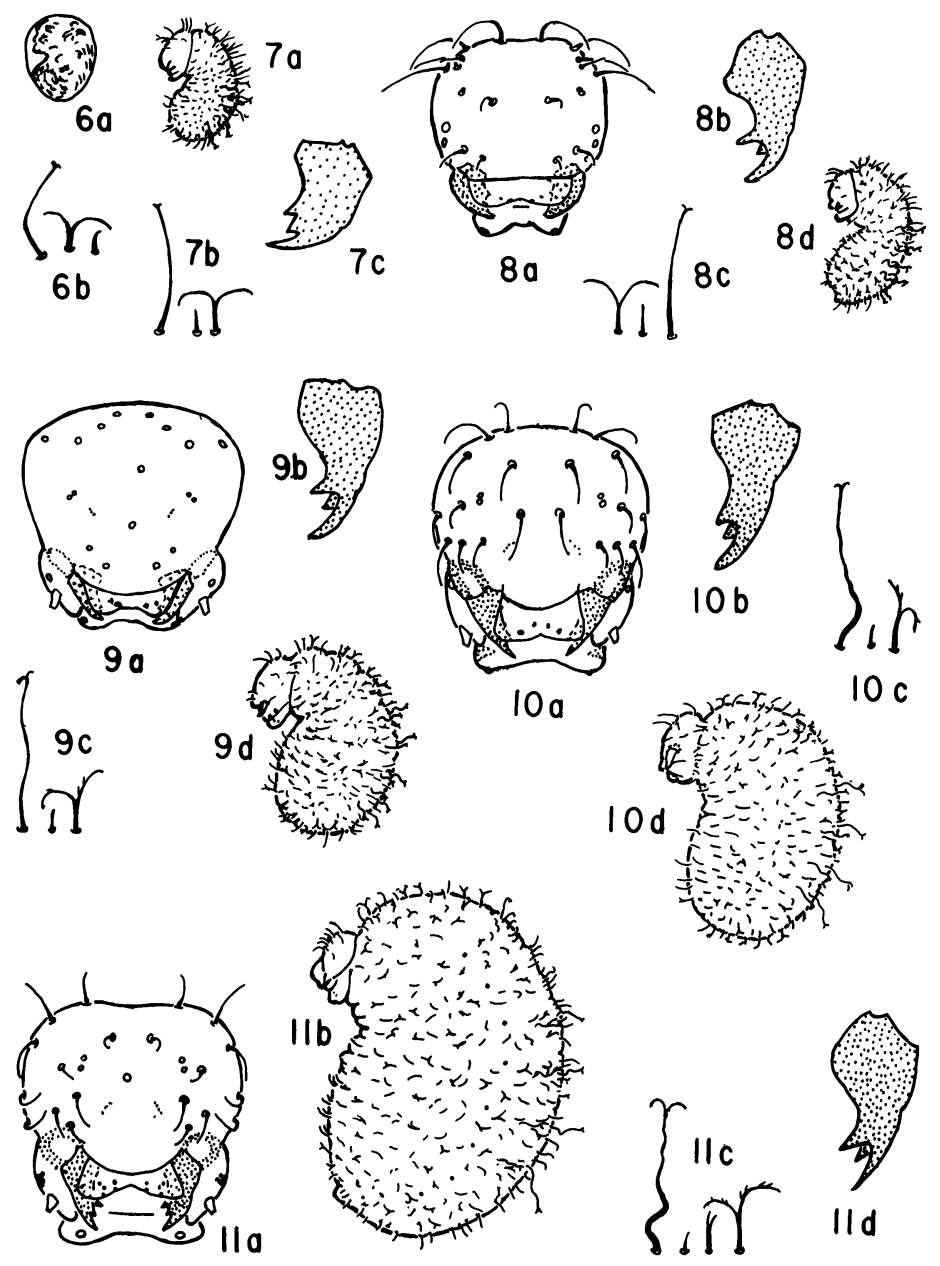

Figures 6-11. Trichoscapa membranifera. $6 \mathrm{a}$, Larva inside egg, $\times 39 ; 6 \mathrm{~b}$, body hairs, $\times 200$. 7, First instar: a, larva in side view, $\times 39$; b, body hairs, $\times 200$; c, left mandible in anterior view, $\times 278$. 8, Second instar: a, head in anterior view, $\times 254$; $\mathrm{b}$, left mandible in anterior view, $\times 278$; c, body hairs, $\times 200$; $d$, larva in side view, $\times 39$. 9, Third instar: a, head in anterior view (hairs omitted), $\times 254$; b, left mandible in anterior view, $\times 278$; c, body hairs, $\times 200$; d, larva inside view, $\times 39$. 10, Fourth instar: $a$, head in anterior view, $\times 254$; b, left mandible in anterior view, $\times 278$; c, body hairs, $\times 200$; d, larva in side view, $\times 39$. 11, Fifth instar (=mature larva): $a$, head in anterior view, $\times 254$; $b$, larva in side view, $\times 39$; c, body hairs, $\times 200$; d, left mandible in anterior view, $\times 278$. 
isolated sensillum between each palp and the opening of the sericteries, the latter a short transverse slit. Hypopharynx with minute spinules in short transverse rows.

Fourth instar. Length (through spiracles) about $1.4 \mathrm{~mm}$. Similar to mature larva except as follows. Thirteen distinct somites. Dorsal outline of cranium entire. Head hairs fewer (about 25); 0.013-0.05 $\mathrm{mm}$ long. Mandibular teeth round-pointed.

Third instar. Length (through spiracles) about $1.2 \mathrm{~mm}$. Similar to fourth instar except as follows. Anus without lips. Type 3 body hairs about $0.075 \mathrm{~mm}$ long. Cranium longitudinally subovoidal. Pleurostoma moderately developed. Mandible with longer apical tooth.

Second instar. Length (through spiracles) about $0.88 \mathrm{~mm}$. Similar to third instar except as follows. Spiracles on T2 $0.004 \mathrm{~mm}$ in diameter, decreasing to $0.003 \mathrm{~mm}$ on AVIII. Body hairs long; (1) 0.013-0.05 mm long, unbranched, slightly curved; (2) 0.013-0.05 $\mathrm{mm}$ long, slightly curved, deeply bifid; (3) about $0.088 \mathrm{~mm}$ long, uncinate. Cranium longitudinally subovoidal. Pleurostoma feeble. Antenna with 2 sensilla. Head hairs $0.025-0.05 \mathrm{~mm}$ long. Maxillary palp an irregular knob with 4 sensilla; galea with broad base and digitiform apex with 2 sensilla. Labial palp a short cylinder with 5 sensilla.

First instar. Length (through spiracles) about $0.036 \mathrm{~mm}$. Similar to second instar except as follows. Diameter of head greater than that of thoracic somites; abdomen strongly curved ventrally. Somites all of about same diameter and distinct. All spiracles $0.0025 \mathrm{~mm}$ in diameter. Body hairs: (1) about $0.013 \mathrm{~mm}$ long, unbranched and slightly curved; (2) $0.025-0.038 \mathrm{~mm}$ long, bifid, with branches short to long; (3) about $0.063 \mathrm{~mm}$ long, with slightly curved shaft, short uncinate tip. Cranium transversely subelliptical; pleurostoma not developed. Antenna represented by 2 or 3 very slightly raised sensilla. Each half of anterior surface of labrum with 2 sensilla. Mandible feebly sclerotized, subtriangular, short and wide with sharp teeth. Maxillary palp a slight elevation with 4 (?) sensilla. Labial palp a slightly raised cluster of 4 contiguous sensilla. No spinules seen on hypopharynx.

Material studied: numerous larvae from Spain courtesy of $\mathrm{X}$. Espadeler. 
Genus COLOBOPSis Mayr

Colobopsis abdita Forel

Figures 12-16

Fifth instar (= mature larva). Length (through spiracles) about $5.2 \mathrm{~mm}$. Similar to Colobopsis mississippiensis (1958:188) and keys to genus (1976:73). Profile pogonomyrmecoid; praesaepium present; anus with small posterior lip; T1-T3 and AI forming a short stout neck which is so strongly curved ventrally that the mouth parts may be directed posterodorsally into praesaepium; remainder of body subellipsoidal. Spiracles decreasing in diameter from $0.019 \mathrm{~mm}$ on T2 to $0.016 \mathrm{~mm}$ on AVIII. Integument on venter of T1, T2 and AVIII-AX with minute spinules. Body hairs sparse, short, uniformly distributed. Of 3 types: (1) $0.025-0.1 \mathrm{~mm}$ long, unbranched; (2) 0.024-0.05 mm long, 2- (rarely 3-) branched, longest near praesaepium with flexuous branches; (3) 0.25-0.7 mm long, unbranched, flexuous, 5-7 on each dorsolateral surface of AII-AVIII. Cranium subquadrangular, widest ventrally; pleurostoma well developed. Antenna of 3 sensilla on a sclerotized base, on a feebly sclerotized ovoid. Head hairs $0.013-0.035 \mathrm{~mm}$ long, numerous (about 140), unbranched and smooth. Labrum paraboloidal with a small midventral projection; anterior surface with 8 sensilla near ventral surface and 2 sensilla; ventral surface with 8 sensilla; posterior surface with short arcuate rows of minute spinules. Mandible camponotoid; anterior, medial and posterior surfaces with longitudinal ridges; apical tooth narrow with tip narrowed and curved medially. Maxilla with base swollen laterally; apex subconical and directed medially; palp a tapered peg with 4 lateral and 1 apical sensilla; galea skewed, digitiform with 2 apical sensilla. Labium small, paraboloidal; palp a short cylinder with 4 (or 5?) projecting sensilla; an isolated sensillum between each palp and the opening of the sericteries, the latter a short transverse slit. Hypopharynx densely spinulose, the spinules arranged in subtransverse rows, the rows grouped in 2 subtriangles which have their bases near the middle.

Fourth instar. Length (through spiracles) about $4.3 \mathrm{~mm}$. Similar to mature larva except as follows. More slender. Segmentation distinct. All spiracles $0.013 \mathrm{~mm}$ in diameter. Body hairs of type (2) 0.025-0.125 mm long; (3) about $0.35 \mathrm{~mm}$ long. Pleurostoma less 


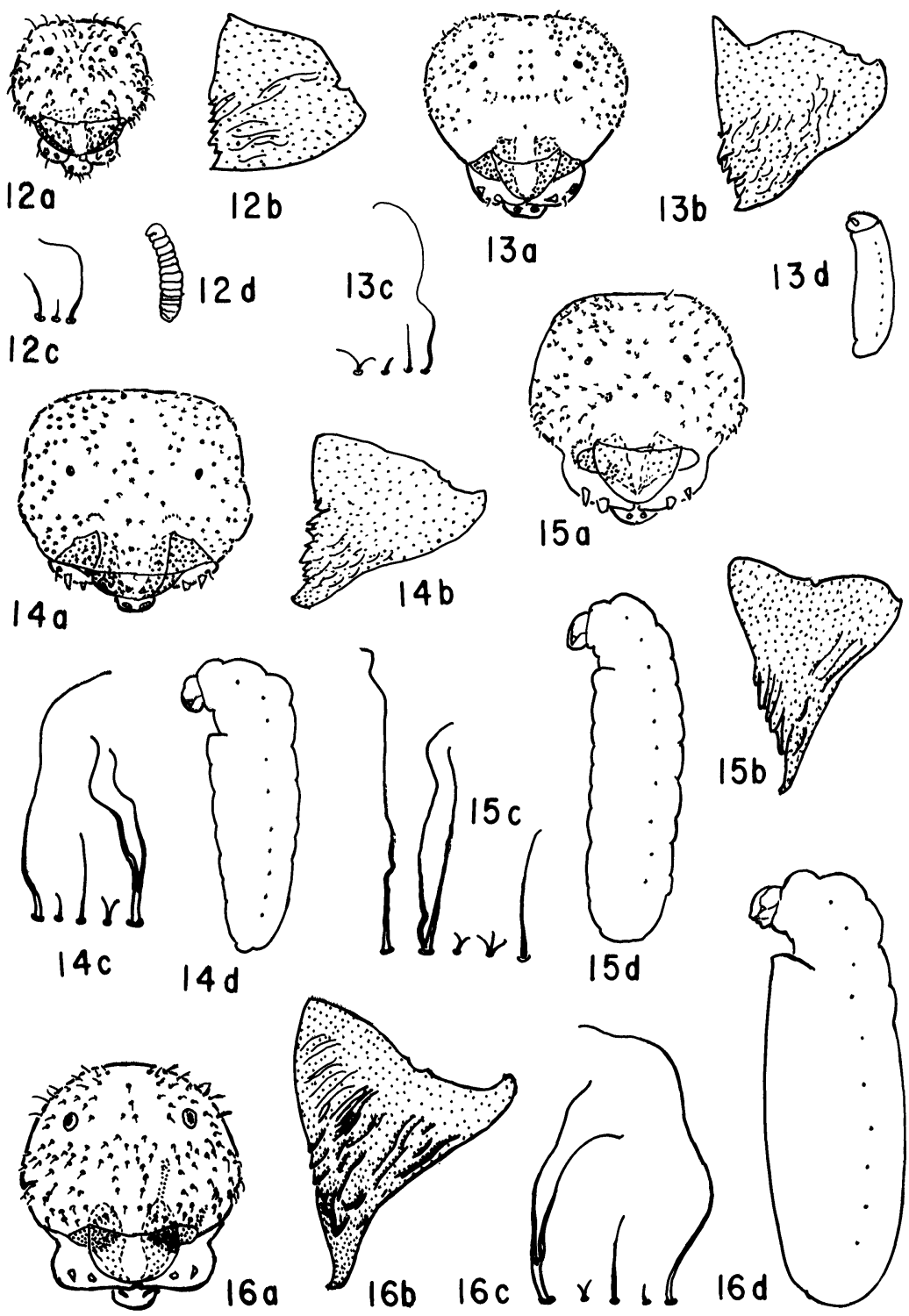

Figures 12-16. Colobopsis abdita. 12, First instar; 13, second instar; 14, third instar; 15, fourth instar; 16, fifth instar (=mature larva). a, Head in anterior view, $\times 56$; b, left mandible in anterior view, $\times 200$; c, body hairs, $\times 100$; d, larva in side view (hairs omitted), $\times 12$. 
sclerotized. Head hairs short $(0.025-0.05 \mathrm{~mm})$ long and more numerous (about 170). Ventral surface of labrum with 6 sensilla; chilosclere less sclerotized. Maxillary palp shorter, 4 lateral and 1 apical sensilla visible. Labial palp a slight elevation with 4 sensilla. Hypopharynx with minute spinules in same pattern as mature.

Third instar. Length (through spiracles) about $2.1 \mathrm{~mm}$. Similar to fourth instar except as follows. Body slightly curved. Body hairs shorter: (1) 0.013-0.06 mm long; (2) 0.03-0.075 mm long; (3) about $0.324 \mathrm{~mm}$ long, slender, flexuous on AI-AX, about 26 on each dorsolateral surface. Pleurostoma feebly developed. About 160 head hairs. Apex of mandible short, acute and pointed medially.

Second instar. Length (through spiracles) about $1.9 \mathrm{~mm}$. Similar to third instar except as follows. Diameter of head greater than diameter of thoracic somites; no praesaepium. Body slightly curved ventrally; head on anterior end. About 4 distinct somites. All spiracles $0.013 \mathrm{~mm}$ in diameter. Type 3 body hairs ca. 0.275 $\mathrm{mm}$ long, flexuous, on AI-AVI. Pleurostoma feebler and only partially developed. Head hairs $0.013-0.05 \mathrm{~mm}$ long; fewer (about 140). Spinules on posterior surface of labrum fewer and very short rows. Mandible subtriangular; apex short and slightly curved medially; apical half of medial border erose; anterior and posterior surfaces with feeble furrows. Base of maxilla less swollen; apex more rounded.

First instar. Length (through spiracles) about $0.96 \mathrm{~mm}$. Similar to second instar except as follows. Segmentation distinct. Spiracles on T2 $0.01 \mathrm{~mm}$ in diameter and on AVIII $0.009 \mathrm{~mm}$. Spinules on venter of T1-AII, few on AVIII-AX. Body hairs very sparse, 0.025-0.275 mm long. Head hairs less numerous (about 95). Mandible feebly sclerotized; subtriangular; apex short, acute and straight. Maxillary base not swollen; apex short and round-pointed. Labial palp an irregular elevation with 5 sensilla. Hypopharynx with minute spinules.

Material studied: about a dozen larvae from Costa Rica courtesy of Diana Wheeler.

\section{REFERENCES}

BROWN, W. L.

1948. A preliminary revision of the higher Dacetini. Trans. Amer. Ent. Soc. 74: 101-129. 
Wheeler, G. C., AND JeAnette Wheeler

1953. The ant larvae of the subfamily Formicinae. Ann. Ent. Soc. Amer. 46:175-217.

1956. The ant larvae of the subfamily Pseudomyrmecinae. Ann. Ent. Soc. Amer. 49: 374-398.

1976. Ant Larvae: Review and Synthesis. Ent. Soc. Washington. Memoir 7. $107 \mathrm{p}$.

1982. Supplementary studies of ant larvae: Formicinae. Psyche 89: 175-181. 

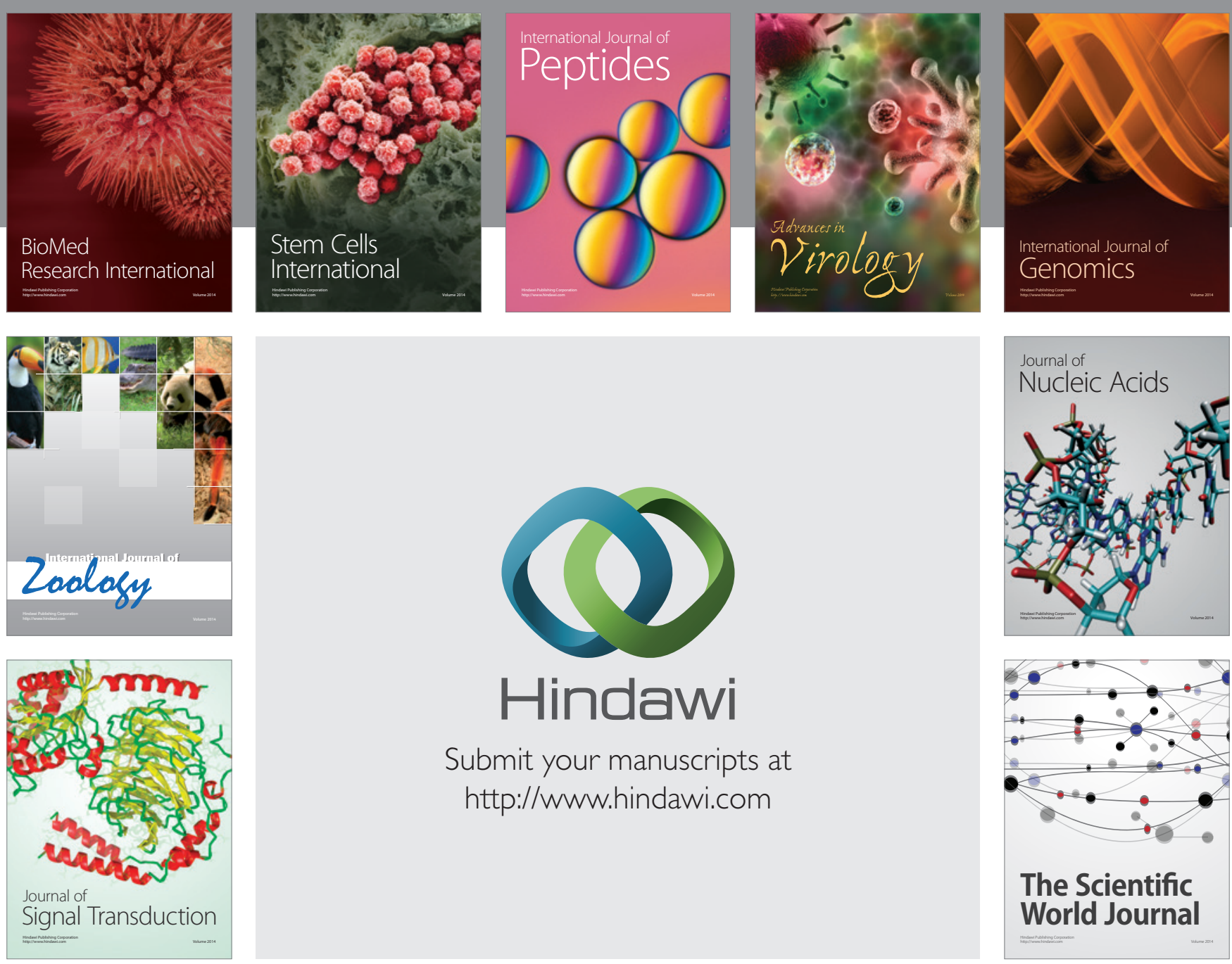

Submit your manuscripts at

http://www.hindawi.com
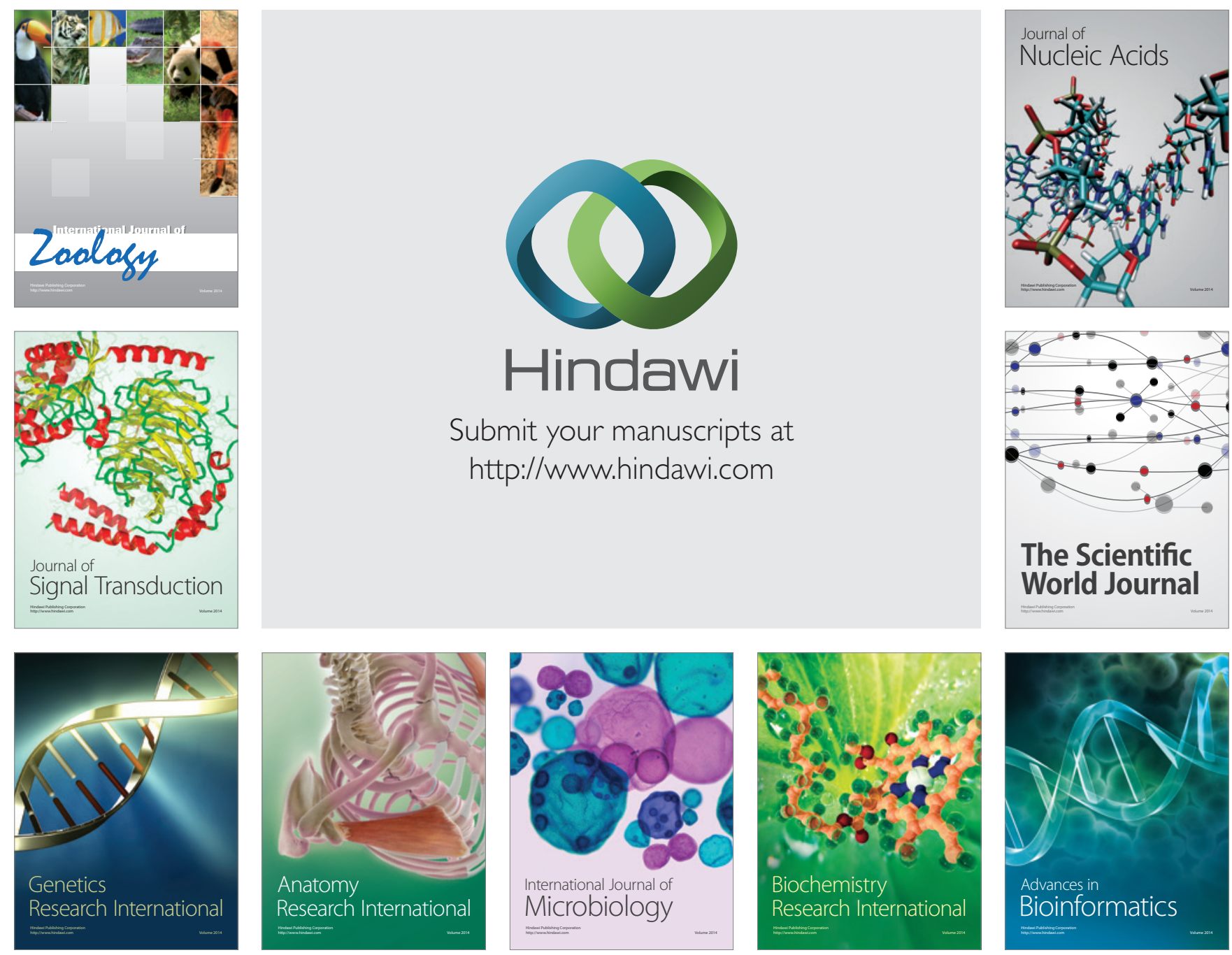

The Scientific World Journal
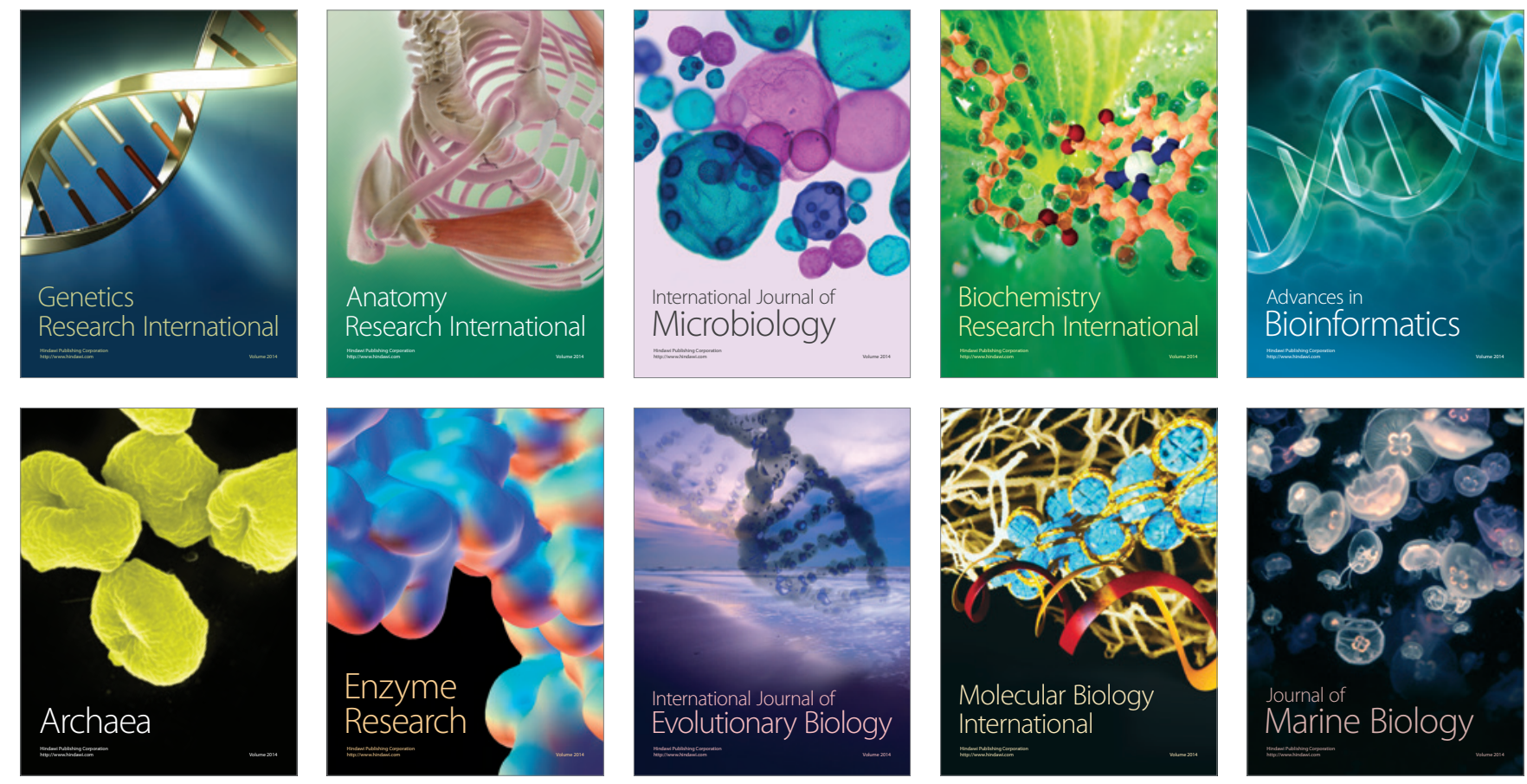